\title{
Thermodynamic Study of the Liquid Cu-O System*
}

\author{
By Yoshiro Kayahara**, Katsutoshi Ono***, Toshio Oishi*** \\ and Joichiro Moriyama***
}

\begin{abstract}
The phase relationships in the liquid $\mathrm{Cu}-\mathrm{O}$ system were determined by the following three experimental techniques, (1) Water quenching of the samples in crucible, (2) Water quenching of the samples after suction into an alumina tube, (3) Emf measurements combined with the suction-water quenching.

The cells used were as follows: $\mathrm{Pt} / \mathrm{Ni}, \mathrm{NiO} / \mathrm{ZrO}_{2}(+\mathrm{CaO}) / \mathrm{O}$ in $\mathrm{Cu}(1)$ or copper oxide (1)/ $\mathrm{LaCrO}_{3} / \mathrm{Pt}, \mathrm{Pt} / \mathrm{Ni}, \mathrm{NiO} / \mathrm{ZrO}_{2}(+\mathrm{CaO}) / \mathrm{O}$ in $\mathrm{Cu}(1)+$ copper oxide (s or 1$) / \mathrm{LaCrO}_{3} / \mathrm{Pt}$.

It was confirmed that the miscibility gap exists between liquid copper and liquid copper oxide and it seems to disappear at higher temperature than $1620 \mathrm{~K}$.

From emf measurements, the activities of oxygen and copper were calculated at $1573 \mathrm{~K}$, and the standard free energies of formation of solid and liquid $\mathrm{Cu}_{2} \mathrm{O}$ were determined in the temperature range from 1370 to $1600 \mathrm{~K}$. Relative partial molar entropy of oxygen in the liquid $\mathrm{Cu}-\mathrm{O}$ system showed a minimum value at or close to the stoichiometric $\mathrm{Cu}_{2} \mathrm{O}$ composition.

The oxygen potential-temperature-composition (P-T-X) diagram for the $\mathrm{Cu}-\mathrm{O}$ binary system was determined from the results of this study.
\end{abstract}

(Received February 7, 1981)

\section{Introduction}

The $\mathrm{Cu}-\mathrm{O}$ system is one of the fundamental systems for copper smelting processes and many thermodynamic studies of this system have been reported. In early studies for the equilibrium phase diagram ${ }^{(1) \sim(4)}$, the miscibility gap between liquid copper and copper oxide has been reported to exist even at higher temperature than $1673 \mathrm{~K}$.

In recent years, Kuxmann and Kurre ${ }^{(5)}$, Gerlach, Osterwald and Stichel ${ }^{(6)}$, and SadatDarbandi ${ }^{(7)}$ have reported that the oxygen solubility in liquid copper at the lower temperature than $1473 \mathrm{~K}$ is in good agreement with the early studies, but the miscibility gap disappears at the temperature near $1620 \mathrm{~K}$ and the homogeneous liquid phase is stable at the high temperatures. It has been supposed that in the early studies quenching of samples was not rapid enough to freeze the dissolved oxygen,

* The major part of this study was originally published in Japanese in J. Japan Inst. Metals, 42 (1978), 527.

** Graduate School, Kyoto University, Kyoto. Present address: Toyota Motor Co., Ltd., Miyoshi-cho, Aichi 470-02, Japan.

*** Department of Metallurgy, Kyoto University, Sakyo-ku, Kyoto 606, Japan. and solution of refractory materials into the liquid oxide also occurred.

In the present investigation, the equilibrium phase diagram for the $\mathrm{Cu}-\mathrm{O}$ binary system mainly in the liquid field was determined using three different experimental techniques and compared with the previous works.

The $\mathrm{H}_{2} / \mathrm{H}_{2} \mathrm{O}^{(8) \sim(11)}$ and $\mathrm{CO} / \mathrm{CO}_{2}^{(12)(13)}$ gas equilibrium methods and the emf method with solid electrolytes ${ }^{(6)(7)(14) \sim(35)}$ have been employed to study the thermodynamic properties of the $\mathrm{Cu}-\mathrm{O}$ binary system. In the present investigation, the relationship among oxygen potential, temperature and oxygen concentration was determined using the zirconia solid electrolyte galvanic cells in the oxygen concentration range from 3 to 34 at \% and at the temperatures from 1430 to $1600 \mathrm{~K}$. From the results of emf measurements, the activities of oxygen and copper, the standard free energies of formation of solid and liquid $\mathrm{Cu}_{2} \mathrm{O}$ and the relative partial molar entropy of oxygen in the liquid $\mathrm{Cu}-\mathrm{O}$ system were also obtained.

\section{Determination of the $\mathrm{Cu}-\mathrm{O}$ Phase Diagram}

\section{Experimental method}

The samples taken with three different 
techniques were analysed for oxygen to determine the $\mathrm{Cu}-\mathrm{O}$ phase diagram of the liquid copper and oxide equilibrium field.

(1) An alumina crucible, $13 \mathrm{~mm}$ OD, 10 $\mathrm{mm}$ ID and $100 \mathrm{~mm}$ long, which contains oxygen free copper of about $10 \mathrm{~g}$ and copper oxide weighed so as to make an oxygen concentration of about $6 \mathrm{wt} \%$ was included in a silica tube. The system was evacuated and purified argon was introduced. The sample was then heated and maintained at a given temperature for $15 \mathrm{ks}$. This holding period was determined from the emf measurements which will be described in the following section. The silica tube containing the alumina crucible and the sample was quenched in water and the sample was analysed for oxygen.

(2) About $220 \mathrm{~g}$ in total weight of copper and copper oxide were equilibrated in an alumina crucible, $40 \mathrm{~mm}$ OD and $34 \mathrm{~mm}$ ID, and the liquid copper and oxide were sampled separately using an $4 \mathrm{~mm}$ ID alumina tube and then quenched in water. The alumina tube for sampling of liquid oxide has a small opening of about $1 \mathrm{~mm}$ in diameter at the position of about $20-30 \mathrm{~mm}$ from the closed bottom end. These copper and copper oxide samples were analysed for oxygen.

(3) The emf measurement-oxygen analysis combination method was employed to determine the oxygen solubility in liquid copper. The emf values changed linearly with temperature both in the one- and two-phase regions in emf vs temperature diagram. After the intersection temperature of these two straight lines was obtained, the melt was heated to the homogeneous liquid region and sampled for oxygen analysis.

A hydrogen reduction method was used for oxygen analysis in copper and copper oxide.

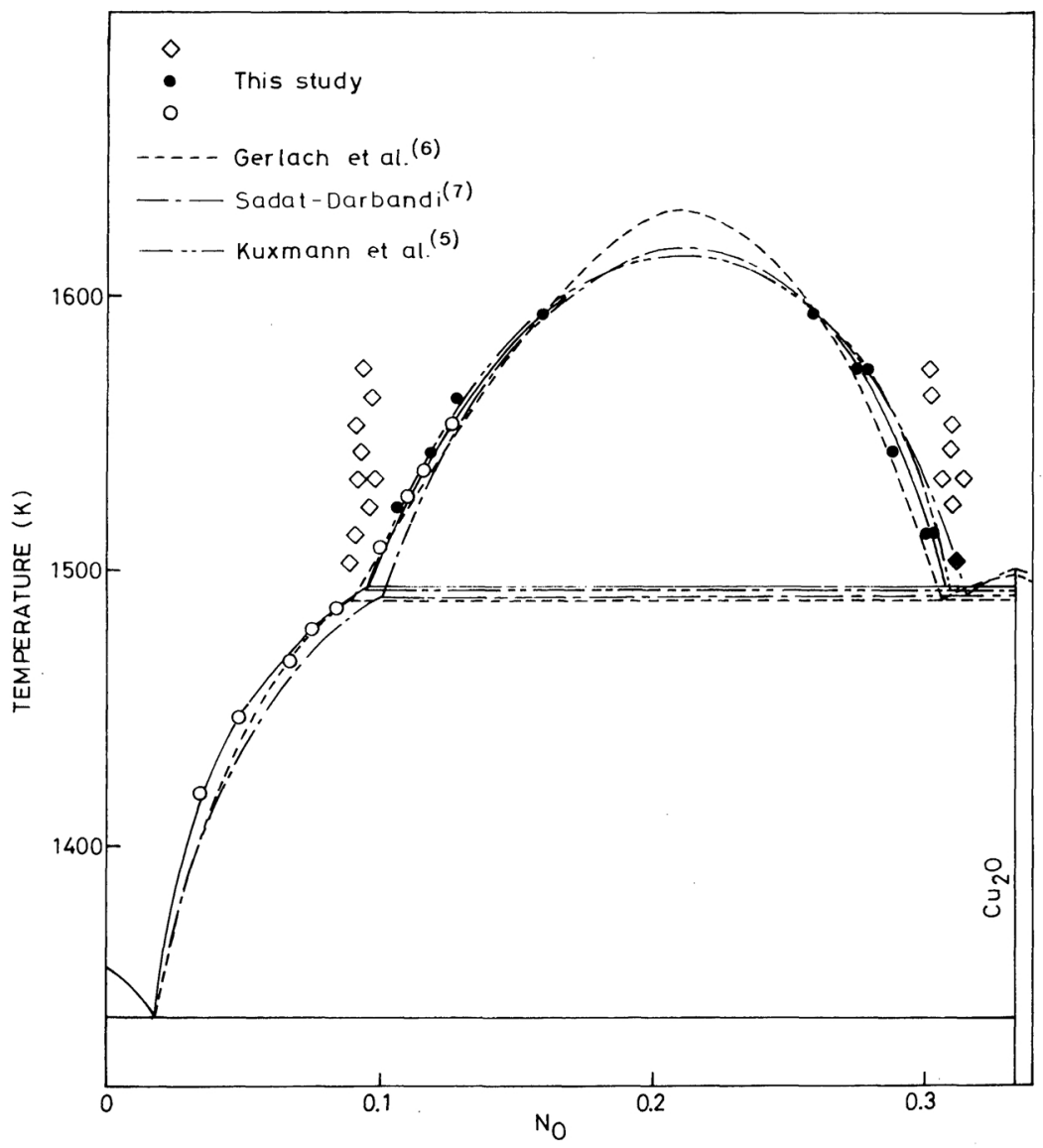

Fig. 1 Equilibrium phase diagram for the $\mathrm{Cu}-\mathrm{O}$ system. 
The oxygen in copper oxide was determined both by weight gain of phosphorus pentoxide and by weight loss of samples. Both results were in good agreement. The oxygen in copper was determined only from the weight gain of phosphorus pentoxide.

\section{Results}

The experimental results obtained by the three different techniques are shown in Fig. 1. In this figure, the quadrangles, the closed circles and the open circles represent the data obtained by the first, second and third techniques, respectively. The temperature dependence of the miscibility gap from the results of first method is very small. It seems that the quenching rate was not rapid enough, because the relatively large volume of sample was in the double wall of alumina crucible and silica tube, so that during quenching the oxygen diffused too fast to keep the state at high temperatures. Whereas the closed and the open circles locate on the same oxygen solubility line. From these results, it was considered that the state at high temperature could be kept by using the second and third sampling methods.

The monotectic temperature was found to be $1495 \mathrm{~K}$ from the results of emf measurements. It is supposed from Fig. 1 that the immiscibility disappears at higher temperature than $1620 \mathrm{~K}$. The data are in good agreement with those of Kuxmann et al. ${ }^{(5)}$ Gerlach et $a .^{(6)}$ and Sadat-Darbandi ${ }^{(7)}$.

\section{Thermodynamic Properties of Oxygen in the Liquid $\mathrm{Cu}-\mathrm{O}$ System}

\section{Experimental apparatus and procedure}

In the present investigation, emf measurements employing solid electrolyte were made on the following galvanic cells in the temperature range from 1370 to $1600 \mathrm{~K}$ :

$$
\begin{aligned}
& \mathrm{Pt} / \mathrm{Ni}, \mathrm{NiO} / \mathrm{ZrO}_{2}(+\mathrm{CaO}) / \mathrm{O} \\
& \text { in } \mathrm{Cu}(1) \text { or copper } \\
& \text { oxide }(1) / \mathrm{LaCrO}_{3} / \mathrm{Pt} \\
& \mathrm{Pt} / \mathrm{Ni}, \mathrm{NiO} / \mathrm{ZrO}_{2}(+\mathrm{CaO}) / \mathrm{O} \\
& \text { in } \mathrm{Cu}(1)+\text { copper }
\end{aligned}
$$

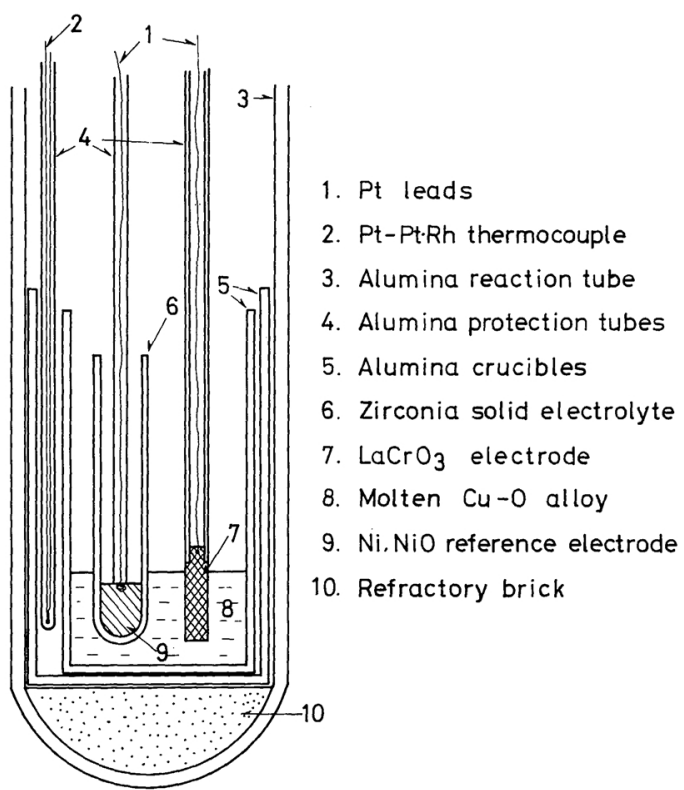

Fig. 2 Cell arrangement.

oxide (s or 1$) / \mathrm{LaCrO}_{3} / \mathrm{Pt}$.

The cell arrangement used is shown in Fig. 2. The cell consisted of a $\mathrm{ZrO}_{2}+11$ mole per cent $\mathrm{CaO}$ solid electrolyte tube, made by Nippon Kagaku Togyo Co., Ltd., which contained the mixtures of nickel and nickel oxide as a reference electrode. The reference electrode was prepared by mixing equal weights of nickel and nickel oxide poweders with a small amount of water and packing the mixtures into the bottom of the zirconia solid electrolyte tube. The spiral end of platinum wire was pushed to the $\mathrm{Ni}, \mathrm{NiO}$ electrode. Good contact was thus obtained between the reference electrode and the electrolyte.

The lead dipped in the melts was made from commercial $\mathrm{LaCrO}_{3}$ rod of about 40-50 $\mathrm{mm}$ long. JACO spectrograph analysis showed that the solubility of $\mathrm{LaCrO}_{3}$ in liquid copper or copper oxide was confirmed to be ignorable.

An alumina was used as a crucible material. In the preliminary experiments, the solubility of alumina in liquid copper oxide showed below $0.5 \%$ at $1573 \mathrm{~K}$.

The furnace used was of the silicon carbide resistance type and its temperature was controlled within an error of $\pm 1 \mathrm{~K}$.

Oxygen free copper of about $100 \mathrm{~g}$ and 


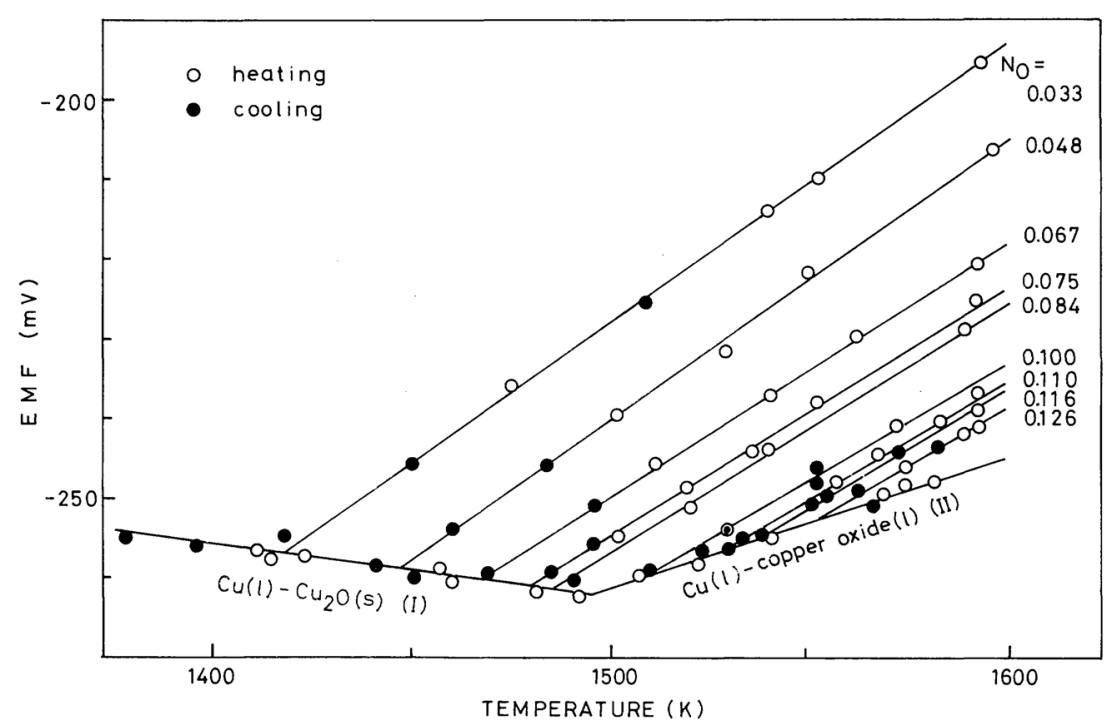

Fig. 3 Variation of emf with temperature for the cell, $\mathrm{Ni}, \mathrm{NiO} / \mathrm{ZrO}_{2}(+\mathrm{CaO}) / \mathrm{Cu}-\mathrm{O}$ liquid alloys.

copper oxide weighed so as to make a certain oxygen concentration were contained in an alumina crucible and placed in a mullite reaction tube, $60 \mathrm{~mm}$ ID. The upper end of the mullite tube was sealed with a water-cooled brass head. After the cell was evacuated at about $670 \mathrm{~K}$ to ensure complete dehydration, purified argon was introduced into the cell. The furnace was then heated to the temperature of experiment. Initial equilibrium of each experimental run was generally attained in several hours after reaching the desired temperature. The emf readings were made with both ascending and descending temperatures in the range from 1370 to $1600 \mathrm{~K}$.

The emf measurements were made with an accuracy of $\pm 0.1 \mathrm{mV}$ using a digital voltmeter (Kuwano Electrical Instruments Co., Ltd.) of input impedance $100 \mathrm{M} \Omega$. The emf values were considered to be steady if the variations were within $\pm 0.5 \mathrm{mV}$ over a period of about $1.2 \mathrm{ks}$.

After each run of emf measurements, the furnace temperature was raised to $1593 \mathrm{~K}$ and the sample was taken by use of a $4 \mathrm{~mm}$ ID silica tube for the liquid copper and $3 \mathrm{~mm}$ ID alumina tube for the liquid oxide, respectively and quenched in water. These samples were analysed for oxygen.

\section{Results}

Figure 3 shows the temperature dependences of emf values for 9 different oxygen concentrations in liquid copper. Open and black

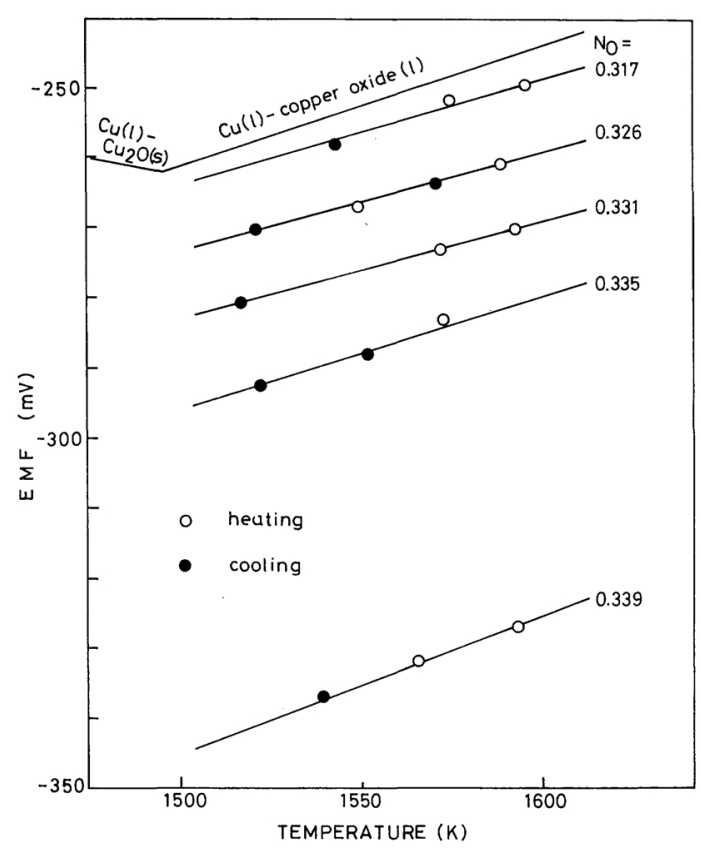

Fig. 4 Variation of emf with temperature for the cell, $\mathrm{Ni}, \mathrm{NiO} / \mathrm{ZrO}_{2}(+\mathrm{CaO}) / \mathrm{Cu}-\mathrm{O}$ liquid oxides. 
circles indicate the emf values measured at ascending and descending temperatures, respectively. The emf values in the single phase region were found to change linearly with temperature. The coefficients of temperature dependence are positive and decrease with increasing oxygen concentration. The lines (I) and (II) correspond to the emf values for the $\mathrm{Cu}(1)-\mathrm{Cu}_{2} \mathrm{O}(\mathrm{s})$ and $\mathrm{Cu}(1)$-copper oxide(1) equilibria, respectively. The intersection temperature of the lines (I) and (II) shows the monotectic temperature and was obtained to be $1495 \mathrm{~K}$.

It is apparent from Fig. 1 that the liquid copper oxide in equilibrium with liquid copper is not stoichiometric. Therefore, in order to determine accurate standard free energy of formation of stoichiometric $\mathrm{Cu}_{2} \mathrm{O}(1)$, emf measurements in both the liquid copper and the oxide fields are needed.

Figure 4 shows emf-temperature relationships for the liquid copper oxide field. The coefficients of temperature dependence are positive and show a minimum at or close to the stoichiometric $\mathrm{Cu}_{2} \mathrm{O}$ composition.

Figure 5 shows the relationship between emf and mole fraction of oxygen $\mathrm{N}_{0}$ at $1573 \mathrm{~K}$ obtained from Figs. 3 and 4. With increasing oxygen content, the emf values decrease at first sharply and then slowly in the liquid copper field, and stay constant in the two phase region. In the liquid oxide field, the emf values decrease slowly up to the oxygen mole fraction of about 0.31 and fall sharply in a higher oxygen content field. Also shown in Fig. 5 are the data of Osterwald et al. ${ }^{(23)}$ and

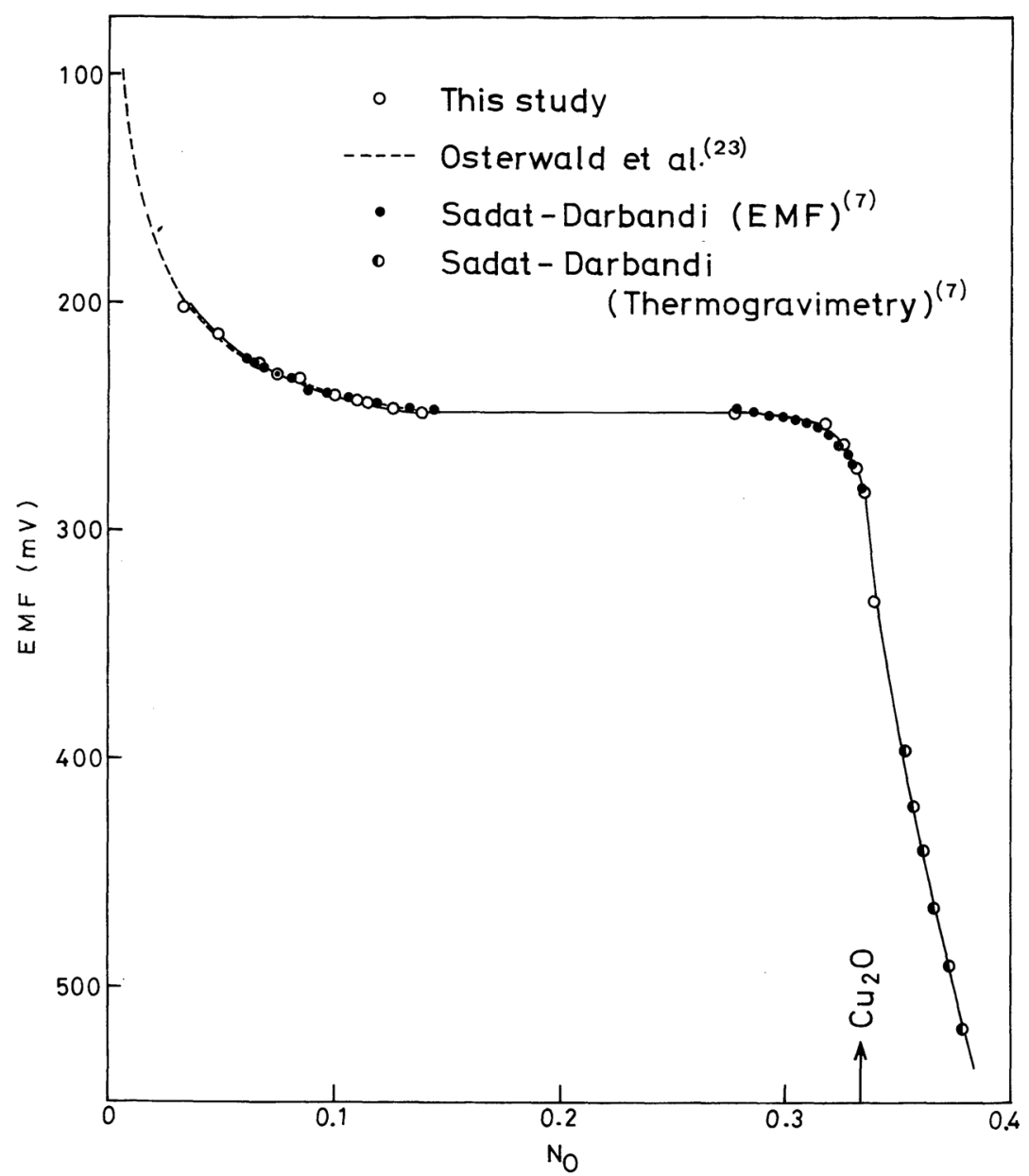

Fig. 5 Relationship between emf and $\mathrm{N}_{0}$ at $1573 \mathrm{~K}$. 
Sadat-Darbandi ${ }^{(7)}$. Their original data are transformed to the equivalent of the cells (I) and (II) by using the standard free energy of formation of $\mathrm{NiO}$.

The activities of oxygen and copper in the $\mathrm{Cu}-\mathrm{O}$ system are shown in Fig. 6. The activity of copper was obtained by applying the GibbsDuhem relation. The activity of oxygen shows a negative deviation from Henry's law. Whereas the activity of copper in the liquid copper field shows a positive deviation from Raoult's law.

\section{Discussions}

As was previously stated, liquid copper is in equilibrium with stoichiometric solid $\mathrm{Cu}_{2} \mathrm{O}$ at temperatures below $1495 \mathrm{~K}$ and in equilibrium with nonstoichiometric liquid $\mathrm{Cu}_{2} \mathrm{O}$ at higher temperatures. The oxygen potentials in these two phase equilibria may be expressed as

$$
\begin{aligned}
\mathrm{Cu}(1)-\mathrm{Cu}_{2} \mathrm{O}(\mathrm{s}): \log \left(p_{\mathrm{O}_{2}} / p_{\mathrm{O}_{2}}^{\circ}\right) \\
\quad=-\frac{2.129 \times 10^{4}}{T}+10.323
\end{aligned}
$$

$\mathrm{Cu}(1)$-copper oxide(1): $\log \left(p_{\mathrm{O}_{2}} / p_{\mathrm{O}_{2}}^{\circ}\right)$

$$
=-\frac{1.424 \times 10^{4}}{T}+5.606
$$

where $p_{\mathrm{O}_{2}}^{\circ}$ denotes $101325 \mathrm{~Pa}$.

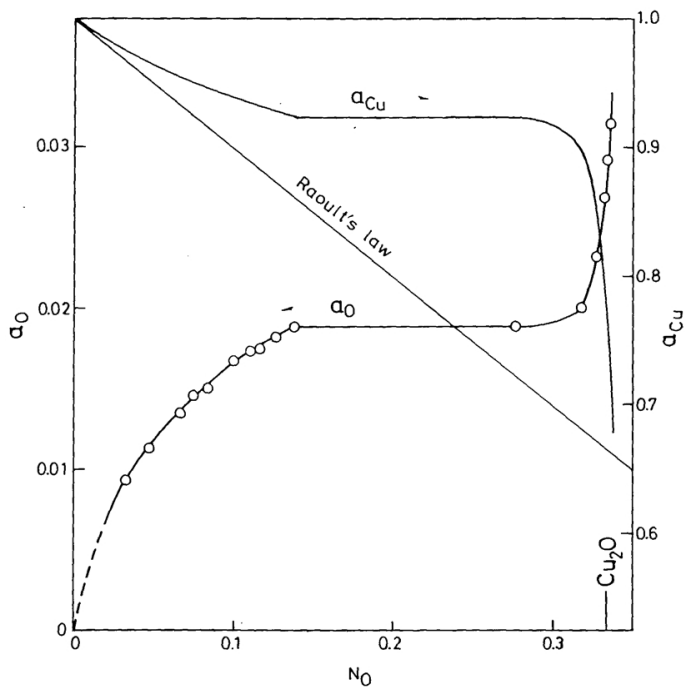

Fig. 6 Activities of oxygen and copper in the liquid $\mathrm{Cu}-\mathrm{O}$ system at $1573 \mathrm{~K}$. Stardard states of oxygen and copper are pure gas at $101325 \mathrm{~Pa}$ and pure liquid copper, respectively.
As can be seen in Fig. 1, the oxygen solubility in liquid copper and the copper solubility in liquid oxide at higher temperatures cannot be neglected. Considering pure copper and stoichiometric $\mathrm{Cu}_{2} \mathrm{O}$ as standard states, the standard free energy of formation of $\mathrm{Cu}_{2} \mathrm{O}$ can be calculated from the results of the present study in the following way. When the stoichiometric $\mathrm{Cu}_{2} \mathrm{O}$ is in equilibrium with copper and oxygen, the standard free energy of formation of $\mathrm{Cu}_{2} \mathrm{O}$ may be expressed by

$$
\Delta G_{\mathrm{Cu}_{2} \mathrm{O}}^{\circ}=-R T \ln a_{\mathrm{Cu}_{2} \mathrm{O}} / a_{\mathrm{Cu}^{2}}^{2} \cdot\left(p_{\mathrm{O}_{2}} / p_{\mathrm{O}_{2}}^{\circ}\right)^{1 / 2},
$$

where $a_{\mathrm{Cu}_{2} \mathrm{O}}$ and $a_{\mathrm{Cu}}$ are activities of $\mathrm{Cu}_{2} \mathrm{O}$ and $\mathrm{Cu}$ at the stoichiometric $\mathrm{Cu}_{2} \mathrm{O}$ composition, respectively, and $a_{\mathrm{Cu}_{2} \mathrm{O}}$ is equal to unity. The values of $a_{\mathrm{Cu}}$ at the stoichiometric $\mathrm{Cu}_{2} \mathrm{O}$ composition were calculated by the Gibbs-Duhem equation at given temperatures. Substituting these values in eq. (1), the standard free energies of formation of $\mathrm{Cu}_{2} \mathrm{O}$ were obtained as a function of temperature and are shown in Fig. 7 together with the results of other investigators.

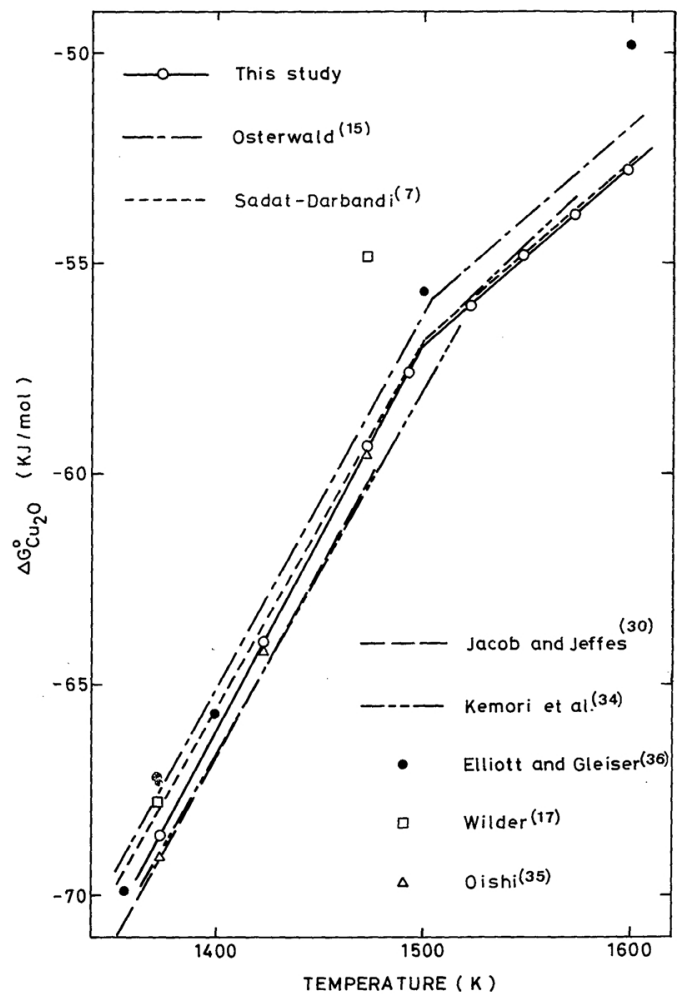

Fig. 7 Standard free energy of formation of $\mathrm{Cu}_{2} \mathrm{O}$. 
The standard free energies of formation of $\mathrm{Cu}_{2} \mathrm{O}$ obtained in the present investigation may be represented by the equations

$\Delta G_{\mathrm{Cu}_{2} \mathrm{O}}^{\circ}(\mathrm{s})=-194.85+91.96 \times 10^{-3} T(\mathrm{~kJ} / \mathrm{mol})$, $\Delta G_{\mathrm{Cu}_{2} \mathrm{O}}^{\circ}(1)=-121.34+42.92 \times 10^{-3} T(\mathrm{~kJ} / \mathrm{mol})$.

The intersection temperature of the two straight lines for $\Delta G_{\mathrm{Cu}_{2} \mathrm{O}(\mathrm{s})}^{\circ}$ and $\Delta G_{\mathrm{Cu}_{2} \mathrm{O}(1)}^{\circ}$ in Fig. 7, $1499 \mathrm{~K}$, is in good agreement with $1503 \mathrm{~K}$ by Osterwald ${ }^{(15)}$ and $1500 \mathrm{~K}$ by SadatDarbandi $^{(7)}$.

Relative partial molar entropies of oxygen in $\mathrm{Cu}-\mathrm{O}$ system calculated from the temperature dependences of the emf values at each oxygen content are plotted in Fig. 8. The relative partial molar entropy of oxygen decreases with increasing oxygen content and shows a minimum at or close to the stoichiometric $\mathrm{Cu}_{2} \mathrm{O}$ composition. This may be interpreted by that the compound $\mathrm{Cu}_{2} \mathrm{O}$ remains at least some extent even in the liquid state.

P-T-X diagram for the $\mathrm{Cu}-\mathrm{O}$ binary system

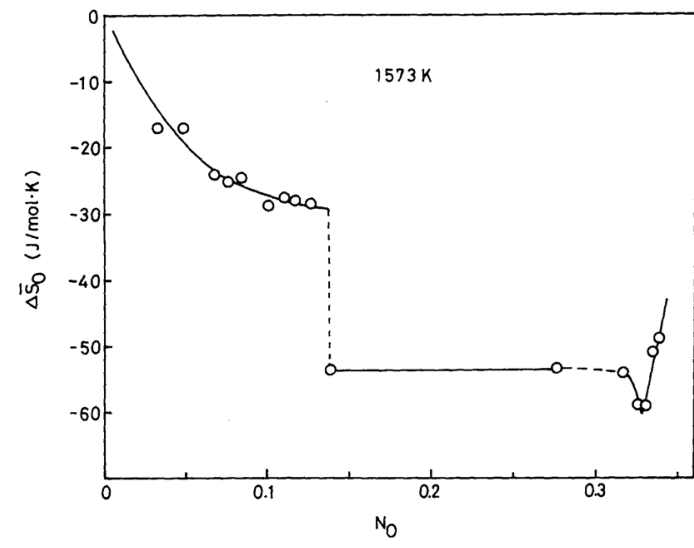

Fig. 8 Relationships between $\Delta \bar{S}_{0}$ and $N_{0}$ at $1573 \mathrm{~K}$.

determined in the present study is shown in Fig. 9. Partial pressures of oxygen, $p_{\mathrm{O}_{2}} / p_{\mathrm{O}_{2}}^{\circ}$, were found to be $10^{-3.0}-10^{-4.5}$ in the oxygen concentration range between 3 and 34 at $\%$ and at a temperature between 1423 and $1600 \mathrm{~K}$.

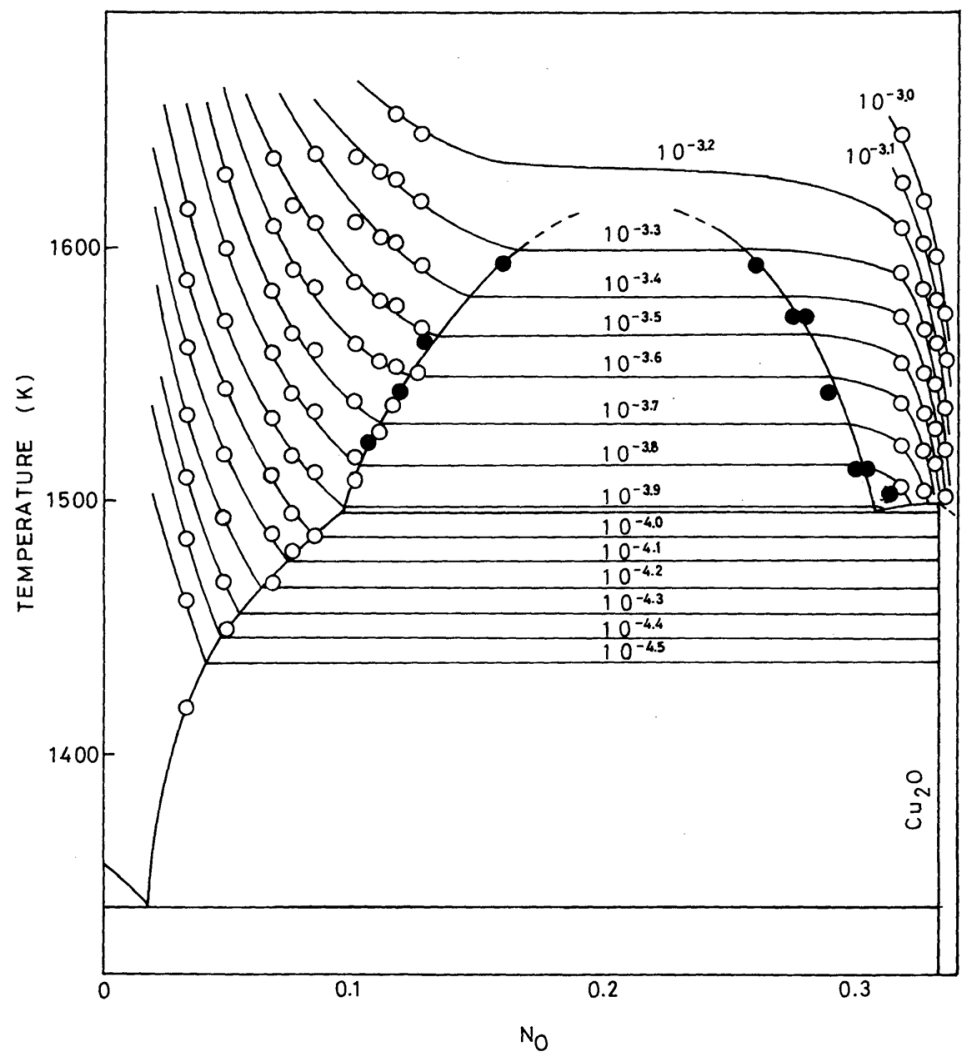

Fig. 9 Oxygen potential-temperature-composition diagram for the $\mathrm{Cu}-\mathrm{O}$ system. 


\section{Summary}

The phase relationship in the liquid $\mathrm{Cu}-\mathrm{O}$ binary system was determined by the following three experimental techniques:

(1) Water quenching of the samples in crucible,

(2) Water quenching of the samples after suction into an alumina tube,

(3) Emf measurements combined with the suction-water quenching.

The cells used were as follows,

$$
\begin{aligned}
& \mathrm{Pt} / \mathrm{Ni}, \mathrm{NiO} / \mathrm{ZrO}_{2}(+\mathrm{CaO}) / \mathrm{O} \\
& \text { in } \mathrm{Cu}(1) \text { or copper } \\
& \text { oxide }(1) / \mathrm{LaCrO}_{3} / \mathrm{Pt} \\
& \mathrm{Pt} / \mathrm{Ni}, \mathrm{NiO} / \mathrm{ZrO}_{2}(+\mathrm{CaO}) / \mathrm{O} \\
& \text { in } \mathrm{Cu}(1)+\operatorname{copper} \\
& \text { oxide(s or } 1) / \mathrm{LaCrO}_{3} / \mathrm{Pt} \text {. }
\end{aligned}
$$

From oxygen analyses, it was found that the miscibility gap seems to disappear at higher temperature than $1620 \mathrm{~K}$.

Using the galvanic cells above mentioned, the activities of oxygen and copper were calculated in the oxygen concentration range from 3 to 34 at $\%$ and the standard free energies of formation of solid and liquid $\mathrm{Cu}_{2} \mathrm{O}$ were determined in the temperature range from 1370 to $1600 \mathrm{~K}$.

Relative partial molar entropy of oxygen in the liquid $\mathrm{Cu}-\mathrm{O}$ system showed a minimum at or close to the stoichiometric $\mathrm{Cu}_{2} \mathrm{O}$ composition.

A P-T-X diagram for the $\mathrm{Cu}-\mathrm{O}$ binary system was also obtained.

\section{REFERENCES}

(1) E. Heyn: Z. Anorg. Allgem. Chem., 39 (1904), 1.

(2) R. E. Slade and F. D. Farrow: Proc. Roy. Soc. (London), A87 (1921), 524.

(3) H. S. Roberts and F. H. Smyth: J. Amer. Chem. Soc., 43 (1921), 1061.

(4) R. Vogel and W. Pocher: Z. Metallk., 21 (1929), $333,368$.

(5) U. Kuxmann and K. Kurre: Erzmetall, 21 (1968), 199.

(6) J. Gerlach, J. Osterwald and W. Stichel: Z. Metallk., 59 (1968), 576.

(7) S. H. Sadat-Darbandi: Dissertation, T. U. Berlin,
(1977).

(8) N. P. Allen and T. Hewitt: J. Inst. Metals, 51 (1933), 257.

(9) U. Block and H. P. Stüwe: Z. Metallk., 60 (1969), 709.

(10) G. R. Belton and E. S. Tankins: Trans. Met. Soc. AIME, 233 (1965), 1892.

(11) H. P. Seow and A. K. Biswas: Proc. Australas. Inst. Min. Met., No 245 (1973), 39.

(12) D. J. Girardi and C. A. Siebert: J. Metals, 188 (1950), 1168.

(13) K. Sano and H. Sakao: J. Japan Inst. Metals, 19 (1955), 431 (in Japanese).

(14) W. Pluschkell and H. J. Engell: Z. Metallk., 56 (1965), 450.

(15) J. Osterwald: Z. Phys. Chem., 49 (1966), 138.

(16) W. A. Fischer and W. Ackermann: Arch. Eisenhüttenw., 37 (1966), 43.

(17) T. C. Wilder: Trans. Met. Soc. AIME, 236 (1966), 1035.

(18) H. Rickert and H. Wagner: Electrochim. Acta, 11 (1966), 83.

(19) M. M. A. El-Naggar, G. B. Horsley and N. A. D. Parlee: Trans. Met. Soc. AIME, 239 (1967), 1994.

(20) C. M. Diaz and F. D. Richardson: Trans. Inst. Min. Met., Sec. C, 76 (1967), C196.

(21) Z. Kozuka, K. Suzuki, T. Oishi and J. Moriyama: J. Japan Inst. Metals, 32 (1968), 1132 (in Japanese).

(22) J. Osterwald: Z. Metallk., 59 (1968), 573.

(23) J. Osterwald, G. Reimann and W. Stichel: Z. Phys. Chem. N.F., 66 (1969), 1.

(24) R. J. Fruehan and F. D. Richardson: Trans. Met. Soc. AIME, 245 (1969), 1721.

(25) W. A. Fischer and G. Pateisky: Arch. Eisenhüttenw., 41 (1970), 661.

(26) C. R. Nanda and G. H. Geiger: Met. Trans., 1 (1970), 1235.

(27) M. M. A. El-Naggar and N. A. D. Parlee: ibid., 1 (1970), 2975.

(28) I. Tsukahara: J. Japan Inst. Metals, 34 (1970), 679 (in Japanese).

(29) G. Frohberg, J. Kramss, J. Pötschke and L. Kapoor: Metall, 25 (1971), 1256.

(30) K. T. Jacob and J. H. E. Jeffes: Trans. Inst. Min. Met., Sec. C, 80 (1971), C32.

(31) A. D. Kulkarni: Met. Trans., 4 (1973), 1713.

(32) P. Taskinen and H. Hiltunen: Scandinavian J. Metallurgy, 8 (1979), 39.

(33) K. Fitzner and Z. Moser: Metals Tech., 6 (1979), 273.

(34) N. Kemori, I. Katayama and Z. Kozuka: Trans. Japan Inst. Metals, 21 (1980), 275.

(35) T. Oishi: Dr. thesis, Kyoto Univ. 1975.

(36) J. F. Elliott and M. Gleiser: Thermochemistry for Steelmaking, Addison-Wesley, (1960), p. 175. 